\title{
INSULIN THERAPY INITIATION IN A PATIENT WITH TYPE 2 DIABETES IN EVERDAY CLINICAL PRACTICE: IS THERE A DELAY?
}

\author{
Slobodan Antić1,2, Dragan Zdravković1,2
}

\begin{abstract}
In everyday clinical practice, there is a large number of patients with poorly regulated type 2 diabetes (T2D), which contributes to the development of chronic complications of diabetes. Delayed initiation of insulin therapy in T2D is a particularly significant cause of poor long-term glucoregulation. There are various reasons for this delay, however, in Serbia as well as in Niš, the center of south Serbia, there is no enough data available. The present study was conducted in order to establish whether there was a delay in initiating insulin therapy in Niš, how long it was delayed in comparison to recommendations and experiences of the others, what was glucoregulation like six months prior to initiation of insulin therapy and whether the insulin therapy should have been initiated at that time.

According to the conducted study, at the time of initiation of insulin therapy, HbA1c was $10.51 \%$, which was significantly higher in relation to other comparable studies. The delay can be considered to be at least 6 months, because at that time HbA1c was $9.63 \%$, and all the criteria for initiation of insulin therapy were met.
\end{abstract}

Acta Medica Medianae 2020;59(3):36-40.

Key words: type 2 diabetes, insulin therapy initiation, $H b A 1 c$, delay

${ }^{1}$ University of Niš, Faculty of Medicine, Niš, Serbia

${ }^{2}$ Clinical Center Niš, Clinic of Endocrinology, Niš, Serbia

Contact: Slobodan Antić

48 Dr Zoran Djindjić Blvd., 18000 Niš, Serbia

E-mail: bataantic@gmail.com

\section{Introduction}

Diabetes related chronic complications are one of the most important factors that have impact on shortening of life expectancy in people with diabetes, as well as the deterioration of the quality of life $(1-4)$.

The two largest and most significant diabetes studies, UKPDS (5-7) and DCCT (8), have unequivocally shown that good glucoregulation is directly related to the reduction especially of microvascular complications (diabetic retinopathy, diabetic polyneuropathy and diabetic nephropathy), but also to reduction of macrovascular complications and death $(8,9)$.

In order to have more successful type 2 diabetes management, referent scientific organizations have set $\mathrm{HbA} 1 \mathrm{C}$ targets to be below $7 \%$ for most of patients, but according to the individual approach, the target can be even lower, between $6.5-8 \%$ (912).
In everyday clinical practice however, there is a large number of patients with poorly regulated type 2 diabetes, which goes in favor of development of chronic complications of diabetes, i.e. comorbidity. Late start of insulin therapy in type 2 diabetes is a great challenge and a great problem. There are various reasons behind, but basically, it is about insufficient education of both patients and doctors (13-18).

Availability of insulin initiation data in Serbia is quite poor, as well as the answer to the question whether the therapy could have been started earlier.

\section{Research objectives}

In accordance with the above mentioned data and performed review of so far available literature, the following research objectives have been set:

1. To examine insulin therapy initiation timeframe in people with type 2 diabetes in relation to glucoregulation.

2. To examine the patient's condition 6 months before insulin therapy introduction, especially in relation to glucoregulation.

\section{Methods and patients}

This study was a prospective-retrospective research that included 70 patients with type 2 diabetes treated at the Clinic for Endocrinology, Diabetes and Metabolic Diseases KC Niš in the year 2015. 
The study included 40 years old patients and older, with a clinically confirmed diagnosis of type 2 diabetes, at least one year before switching to insulin therapy.

The study included anamnestic and clinical data analysis according to predefined research protocol: at the time of insulin therapy introduction, 6 months before and 6 months after.

All patients were informed in details about the study. Anamnestic data were obtained by a survey questionnaire. Two survey questionnaires (Appendix 10.1 and 10.2) were used throughout the study, and the clinical trial protocol 10.3 was divided into two time intervals:

- Clinical trial protocol 1 , which refers to the condition at the time of insulin therapy introduction (Appendix 10.3.1);

- Clinical trial protocol 2, which refers to the patient's condition 6 months before insulin therapy introduction (Appendix 10.3.2).

Statistical data analysis was performed with the SPSS 15.0 software package. Data analysis results are presented in tables and graphs.
Continuous variables are represented by mean values and standard deviations ( $X \pm S D)$ and medians as a measure of central tendency (Me). Category variables are given as absolute numbers and percentages.

\section{Results}

The study included 70 subjects with an average age of $60.97 \pm 9.83$ years, with a median of 60 years.

Out of the total number of participants, 29 $(41.43 \%)$ patients were male and 41 (58.57\%) were female (Table 1). Patients' age structure is shown in the table.

Female participants were slightly older than the males, but statistically not significant.

The average DM duration was $11.11 \pm 6.31$ years, and the median duration was 10 years (Table 2).

Table 1. Patients'age/sex characteristics

\begin{tabular}{|c|ccc||}
\cline { 2 - 4 } \multicolumn{1}{c||}{} & \multicolumn{3}{c|}{ Age (years) } \\
\multicolumn{1}{c||}{} & $\mathrm{X} \pm$ & $\mathrm{SD}$ & $(\mathrm{Me})$ \\
\hline Male & $58,55 \pm$ & 9.12 & $(58.00)$ \\
Female & $62.68 \pm$ & 10.06 & $(62.00)$ \\
\hline Total & $60.97 \pm$ & 9.83 & $(6000)$ \\
\hline
\end{tabular}

Table 2. DM duration

\begin{tabular}{|c|ccc||}
\cline { 2 - 4 } \multicolumn{1}{c||}{} & \multicolumn{3}{c||}{ DM duration (years) } \\
\multicolumn{1}{c||}{$\mathrm{X} \pm$} & $10.34 \pm$ & 5.63 & $(10.00)$ \\
\hline Male & $11.66 \pm$ & 6.77 & $(10.00)$ \\
Female & $11.11 \pm$ & 6.31 & $(10.00)$ \\
\hline Total & & & \\
\hline
\end{tabular}

High value of standard deviation indicates the inhomogeneity of this parameter in the examined sample, which is supported by the fact that the minimum of DM duration is one, and the maximum is 38 years. Female subjects have longer DM duration, but not statistically significantly longer vs. male subjects.

Glycosylated hemoglobin ( $\mathrm{HbA1c}$ ) values at the time of transition to insulin therapy were
$10.51 \%$, which is statistically significantly higher than 6 months before conversion to insulin $(0.88 \%)$ (Table 3).

Kohen's d indicates the average effect of drug therapy in the period of 6 months before insulin initiation (Table 4).

Fasting glycemia also increased at the time of insulin initiation vs. 6 months before. 
Table 3. $\mathrm{HbA} 1 \mathrm{c} \%$ at insulin therapy initiation and 6 months before

\begin{tabular}{|c|c|c|c|c|c|}
\hline \multicolumn{6}{|c|}{$\mathrm{HbA} 1 \mathrm{c} \%$} \\
\hline \multicolumn{3}{|c|}{ Insulin therapy initiation } & \multicolumn{3}{|c|}{$\begin{array}{l}6 \text { months before } \\
\text { insulin therapy initiation }\end{array}$} \\
\hline $10.51 \pm$ & 1.49 & $(10.50)$ & $9.63 \pm$ & 1.18 & ${ }^{* * *}(9.65)$ \\
\hline \multicolumn{3}{|c|}{$\Delta$ (Pr. -6 months before) } & \multicolumn{3}{|c|}{$\Delta$ (Pr. -6 months after) } \\
\hline $0.88 \pm$ & 1.16 & $(0.85)$ & $2.24 \pm$ & 1.10 & $(2.00)$ \\
\hline
\end{tabular}

Table 4. Fasting glycemia $(\mathrm{mmol} / \mathrm{l})$ at the time of insulin initiation, and 6 months before insulin initiation

\begin{tabular}{|c|c|c|c|c|c|}
\hline \multicolumn{6}{|c|}{ Fasting glycemia $(\mathrm{mmol} / \mathrm{l})$} \\
\hline \multicolumn{3}{|c|}{ Insulin initiation } & \multicolumn{3}{|c|}{6 months before } \\
\hline $12.40 \pm$ & 2.86 & $(12,15)$ & $11.81 \pm$ & 2.61 & $(11.50)$ \\
\hline \multicolumn{3}{|c|}{$\Delta$ (Pr. - 6 months before) } & \multicolumn{3}{|c|}{$\Delta$ (Pr. -6 months after) } \\
\hline $0.59 \pm$ & 3.39 & $(0.75)$ & $3.84 \pm$ & 2.88 & $(3.45)$ \\
\hline
\end{tabular}

\section{Discussion}

The study included 70 patients - 41 women (59\%) and 29 men (41\%). The mean age of the patients was 60.97 years. This finding was comparable to similar studies.

Duration of diabetes in our patients was 11.11 years, which is more than in patients in Germany's study INSTIGATE (19), where the insulin therapy is initiated much earlier.

The data about average diabetes duration might be considered with caution since establishing diagnosis of diabetes is often significantly delayed in real life. Evidences of elderly patients with a short known duration of diabetes, duration of around one year, but with marked hyperglycemia and already present complications of diabetes are supporting this claim (20).

Data about glycaemic control and especially in relation to $\mathrm{HbA1C}$, are the most significant finding in the study and they are showing that insulin therapy is initiated with an average hemoglobin of $10.51 \%$. This value of $\mathrm{HbA} 1 \mathrm{c}$ is significantly higher than in all comparable studies conducted in Europe and America $(19,21-25)$. In a similar study (INSTIGATE) (19) in Germany and Spain, insulin therapy was initiated at $\mathrm{HbA} 1 \mathrm{C} 9.2 \%$ and in Greece $9.7 \%$. In the BiAsp/Glargine (21) study conducted in the USA, at the time of insulin administration $\mathrm{HbA1C}$ was $9.0 \%$, while in the BIAsp-1556 study in Serbia HbA1c was $10.68 \%$. The BIAsp study was conducted in Serbia and was among the first studies to indicate the late initiation of insulin therapy. $(26,27)$.

Compared to the period of 6 months before initiation of insulin therapy, there was a significant increase in $\mathrm{HbA} 1 \mathrm{c}$ by $0.88 \%$, which unequivocally showed that all patients could be introduced with insulin therapy even 6 months earlier, due to the fact that $\mathrm{HbA} 1 \mathrm{c}$ was $9.63 \pm 1.18 \%$ at that time. Even UKPDS $(8,9)$ study have shown that decrease in $\mathrm{HbA} 1 \mathrm{c}$ values by only $1 \%$ leads to a reduced risk of microvascular complications by $33 \%$ (5-7). Delay of insulin therapy initiation did not bring any benefit to patients, but on the contrary an increase in $\mathrm{HbA} 1 \mathrm{c}$, which, according to available knowledge, increases the risk of late complications of diabetes (28).

\section{Conclusion}

In patients with type 2 diabetes on (sub) maximal therapy with oral hypoglycemics that have been poorly regulated for a long period of time, the initiation of insulin therapy is often delayed. Insulin therapy was initiated to patients in our research at $\mathrm{HbA} 1 \mathrm{C}$ of $10.51 \%$, which is significantly higher than in comparable studies in Europe and USA. This delay might be considered to be at least 6 months since the tests performed at that time (HbA1c - 9.63\%) are suggesting that even then all the criteria for insulin therapy initiation were present. 


\section{References}

1. Wattanakita K, Folsoma AR, Selvinb E, Weatherleyc B, Pankowa J, Brancatib FL, et al. Risk factors for peripheral arterial disease incidence in persons with diabetes: the Atherosclerosis Risk in Communities (ARIC) Study. Atherosclerosis 2005;180:389-97. [CrossRef][PubMed]

2. Khaw KT, Wareham N, Bingham $S$, Luben $R$, Welch $A$, Day N. Association of hemoglobin A1c with cardiovascular disease and mortality in adults: the European Prospective Investigation into Cancer in Norfolk. Ann Intern Med 2004;141:413-20. [CrossRef][PubMed]

3. Đinđić B, Radić S, Antić S, Sokolović D. Znaćaj glikoregulacije u patogenezi koronarne bolesti srca u dijabetes melitusu. Acta Medica Medianae 2000;4:12-8.

4. Selvin E, Marinopoulos S, Berkenblit G, Rami T, Brancati $\mathrm{F}$, Powe N, et al. Meta-analysis: glycosylated hemoglobin and cardiovascular disease in diabetes mellitus. Ann Intern Med 2004;141:421-31. [CrossRef][PubMed]

5. UKPDS. Intensive blood-glucose control with sulphonylureas or insulin compared with conventional treatment and risk of complications in patients with type 2 diabetes (UKPDS 33). UK Prospective Diabetes Study (UKPDS) Group. Lancet 1998;352:837-53. [CrossRef][PubMed]

6. Holman RR, Paul SK, Bethel MA, Matthews D, Neil A. 10-Year follow-up of intensive glucose control in type 2 diabetes. N Engl J Med 2008;359:1577-89.

[CrossRef][PubMed]

7. Stratton IM, Adler IM, Neil HA, Matthews DR, Manley $\mathrm{SD}$, Cull CA. Association of glycaemia with macrovascular and microvascular complications of type 2 diabetes (UKPDS 35): prospective observational study. BM] 2000;321:405-12. [CrossRef][PubMed]

8. The Diabetes Control and Complications Trial Research Group. The effect of intensive treatment of diabetes on the development and progression of long-term complications in insulin-dependent diabetes mellitus. N Engl J Med 1993;329:977-86. [CrossRef][PubMed]

9. Republička stručna komisija za izradu i implementaciju vodiča u kliničkoj praksi. Prevencija tipa 2 dijabetesa. Nacionalni vodič za lekare u primarnoj zdravstvenoj zaštiti. Drugo izmenjeno i dopunjeno izdanje. Beograd: Ministarstvo zdravlja Republike Srbije, jul 2012.

10. Buse J, Wexler D, Tsapas A, Rossing P, Mingrone G, Mathieu $C$, et al. 2019 update to: Management of hyperglycaemia in type 2 diabetes. A consensus report by the American Diabetes Association (ADA) and the European Association for the Study of Diabetes (EASD). Diabetologia 2020;63:221-8. [CrossRef][PubMed]

11. Virally M, Blicklé J-F, Girard J, Halimi S, Simon D, Guillausseau P.-J. Type 2 diabetes mellitus: epidemiology, pathophysiology, unmet needs and therapeutical perspectives. Diabetes Metab 2007;33(4): 231-44. [CrossRef][PubMed]

12. Diabetes Canada Clinical Practice Guidelines Expert Committee. Pharmacologic Glycemic Management of Type 2 Diabetes in Adults. Can J Diabetes 2018;42: S88-S103. [CrossRef][PubMed]

13. Raskin P, Allen E, Hollander P, Lewin A, Gabbay RA, $\mathrm{Hu} P$, et al. Initiating insulin therapy in type 2 diabetes: a comparison of biphasic and basal insulin analogs. Diabetes Care 2005;28:260-65. [CrossRef][PubMed]

14. Hermansen $K$, Mortensen LS, Hermansen ML. Combining insulins with oral antidiabetic agents: effect on hyperglycemic control, markers of cardiovascular risk and disease. Vase Health Risk Manag 2008;4:561-74. [CrossRef][PubMed]

15. Holman RR, Thome KI, Farmer AJ, Davies M, Keenan J, Paul S, et al. Addition of biphasic, prandial, or basal insulin to oral therapy in type 2 diabetes. $\mathrm{N}$ Engl J Med 2007;357:1716-30. [CrossRef][PubMed]

16. Karel K, Wolfgang R. Changes in time to insulin initiation in type 2 diabetes patients: A retrospective database analysis in Germany and UK (2005-2010). Prim Care Diabetes 2013;7(3):229-33. [CrossRef][PubMed]

17. Hirsch IB, Bergenstal RM, Parkin CG, Wright E, Buse JB. A real-world approach to insulin therapy in primary care practice. Clinical Diabetes 2005;23:78-86. [CrossRef]

18. Jenkins $\mathrm{N}$, Hallowell $\mathrm{N}$, Farmer $\mathrm{AJ}$, Holman $\mathrm{R}$, Lawton J. Initiating insulin as part of the treating to target in type 2 diabetes (4-T) trial: an interview study of patients' and health professionals' experiences. Diabetes Care 2010;33:2178-80. [CrossRef][PubMed]

19. Liebl A, Jones S, Goday A, Benroubi M, Castell C, Haupt $A$, et al. Clinical Outcomes After Insulin Initiation in Patients with Type 2 Diabetes: 24-Month Results from INSTIGATE. Diabetes Ther 2012;3(1):9-19. [CrossRef][PubMed]

20. Chun J, Strong J, Urquhart S. Insulin Initiation and Titration in Patients With Type 2 Diabetes. Diabetes Spectrum 2019;32(2):104-11. [CrossRef][PubMed]

21. Ligthelm R, Gylvin T, De Luzio T, Raskin P. A Comparison of Twice-Daily Biphasic Insulin Aspart 70/30 and Once-Daily Insulin Glargine in Persons with Type 2 Diabetes Mellitus Inadequately Controlled on Basal Insulin and Oral Therapy: A Randomized, OpenLabel Study. Endocr Pract 2011;17(1):1-10. [CrossRef][PubMed]

22. Oguz A, Benroubi $M$, Brismar $K$, Melo $P$, Morar C, Cleall SP, et al. Clinical outcomes after 24 months of insulin therapy in patients with type 2 diabetes in five countries: results from the TREAT study. Curr Med Res Opin 2013;29(8):911-92. [CrossRef][PubMed]

23. Perez-Nieves M, Kabul S, Desai U, Ivanova J, Kirson $\mathrm{N}$, Cummings $\mathrm{A}$, et al. Basal insulin persistence, associated factors, and outcomes after treatment initiation among people with type 2 diabetes mellitus in the US. Curr Med Res Opin 2016;32(4):669-80. [CrossRef][PubMed]

24. Brismar K, Benroubi M, Nicolay C, Schmitt H, Giaconia J, Reaney M. Evaluation of insulin initiation on resource utilization and direct costs of treatment over 12 months in patients with type 2 diabetes in Europe: results from INSTIGATE and TREAT observational studies. J Med Econ 2013;16 (8):1022-35. [CrossRef][PubMed]

25. Russell-Jones D, Vaag A, Schmitz O, Sethi BK, Lalic N, Antic $S$, et al. Liraglutide vs insulin glargine and placebo in combination with metformin and sulfonylurea therapy in type 2 diabetes mellitus (LEAD-5 met+SU): a randomised controlled trial. Diabetologia 2009;2 (10):2046-55. [CrossRef] [PubMed]

26. Velojic-Golubovic $M$, Mikic $D$, Pesic $M$, Dimic $D$, Radenkovic S, Antic S. Biphasic insulin aspart 30: Better glycemic control than with premixed human insulin 30 in obese patients with Type 2 diabetes. J Endocrinol Invest 2009;32(1):23-27. [CrossRef][PubMed]

27. Lalic NM, Micic $D$, Antic $S$, Bajovic $L$, Pantelinac $P$, Jotic $A$, et al. Effect of biphasic insulin aspart on glucose 
and lipid control in patients with Type 2 diabetes mellitus. Expert Opin Pharmacother 2007;8(17): 2895-901. [CrossRef][PubMed]

28. American Diabetes Association. Pharmacologic Approaches to Glycemic Treatment: Standards of
Medical Care in Diabetes Pharmacologic Approaches to Glycemic Treatment. Diabetes Care 2020;43(1): S98S110. [CrossRef][PubMed]

\title{
DA LI SE KASNI SA UVOĐENJEM INSULINSKE TERAPIJE KOD BOLESNIKA SA DIJABETESOM TIP 2 U KLINIČKOJ PRAKSI?
}

\author{
Slobodan Antić1,2, Dragan Zdravković1,2 \\ ${ }^{1}$ Univerzitet u Nišu, Medicinski fakultet, Niš, Srbija \\ ${ }^{2}$ Klinički centar Niš, Klinika za endokrinologiju, Niš, Srbija \\ Kontakt: Slobodan Antić \\ Bulevar dr Zorana Đinđića 48, 18000 Niš, Srbija \\ E-mail: bataantic@gmail.com
}

U svakodnevnoj kliničkoj praksi, veliki broj bolesnika sa dijabetesom tip 2 (T2D) je loše regulisan, što doprinosi nastanku hroničnih komplikacija dijabetesa. Kasno otpočinjanje insulinske terapije u T2D predstavlja posebno značajan uzrok dugotrajno loše glikoregulacije. Postoje različiti uzroci ovog kašnjenja, ali u Srbiji, kao i u Nišu, kao centru juga Srbije, nema dovoljno raspoloživih podataka. Da bi utvrdili da li kašnjenja u otpočinjanu insulinske terapije ima u Nišu, koliko je kašnjenje u odnosu na preporuke i iskustva drugih, kakva je glikoregulacija bila šest meseci pre otpočinjanja insulinske terapije i da li je tada trebalo otpočeti insulinsku terapiju, sproveli smo navedeno ispitivanje.

Prema sprovedenom ispitivanju, u vreme otpočinjanja insulinske terapije HbA1c bio je $10,51 \%$, što je značajno više u odnosu na druge komaparabilne studije. Može se smatrati da je kašnjenje najmanje 6 meseci, jer je tada HbA1c bio 9,63\% i bili su ispunjeni svi kriterijumi za otpočinjanje insulinske terapije.

Acta Medica Medianae 2020;59(3):36-40. odlaganje

Ključne reči: dijabetes mellitus tip 2, otpočinjanje insulinske terapije, $H b A 1 c$, 